\title{
The Culture Hero in China: Yu the Great
}

\author{
Haiyan Liu* \\ College of Foreign Languages, Xiangtan University, Hunan province, China
}

Submission: April 15, 2018; Published: May 07, 2018

*Corresponding author: Haiyan Liu, College of Foreign Languages, Xiangtan University, Hunan province, China, Email: 653829290@qq.com

Keywords: Geological evidence; Dredging; Xia dynasty; Archaeology; Geology; History; Catastrophic flood; Great Flood; Historiographies; Hoaxes culture; Jiading period; Reputation; Chinese civilization; Hunan province; Confucian rulership

\section{Opinion}

Recently, a new discovery challenging the traditional thoughts on the origins of Chinese civilization has provoked controversy in the field of archaeology, geology, history, and other relevant disciplines, because it has presented" geological evidence for a catastrophic flood in the early second millennium BCE and suggest that it may be the basis of the Great Flood, thereby lending support to the historicity of the Xia dynasty" (Wu 580).Before this, although many historiographies, such as Shangshu (Book of Documents) and Shiji (Records of the Grand Historian by Sima Qian), have recorded the heroic deeds of Yu the Great who tamed the Great Flood by dredging, leading to the establishment of China's first dynasty, the Xia, and the beginning of Chinese civilization, yet most scholars see Yu the Great as a legendary fabricate to justify the ideological foundations for the Confucian ruler ship system and political succession. Although inviting refutations, the finding might be taken as a great attempt to reconstruct and revive Hoaxes culture.

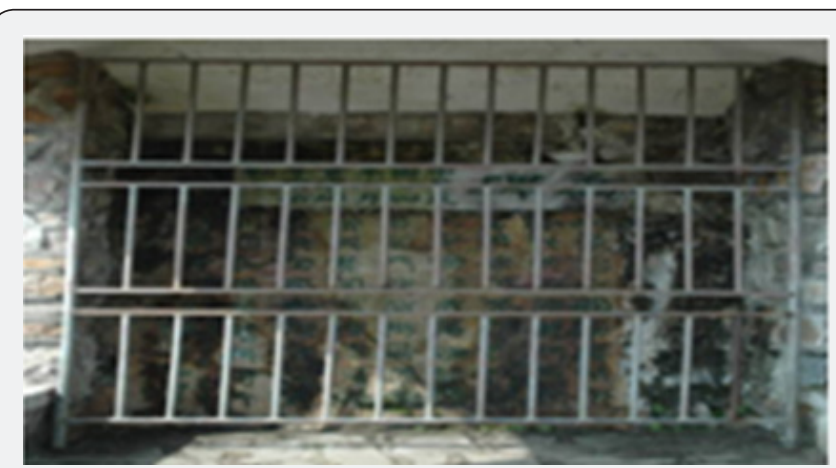

Figure 1: Yuwang Bei (Yu Stele) in the Yuelu Mountain. Photo is taken by the author.

As for Yu's heroic deeds, apart from the above geological evidence and textual accounts, inscriptions on the stones have been dug out on the mountains all over the country. Yuwang
Bei (abbreviated as Yu Stele)located in the north peak of Yuelu Mountain (the seventy-second peak of Mount Hengshan range) in Hunan province, is thought to be the extant earliest surviving one, and other related are the copies from it (Figure 1).

Enjoying a high reputation as one of the three most precious treasure in China, YuStele (also known as the Goulou Stele, the Xia Stele or God Yu Stele) now is under strict protection, and no one is permitted to approach it. We might take a much clearer look at the rubbing from the rock (Figure 2) [1].

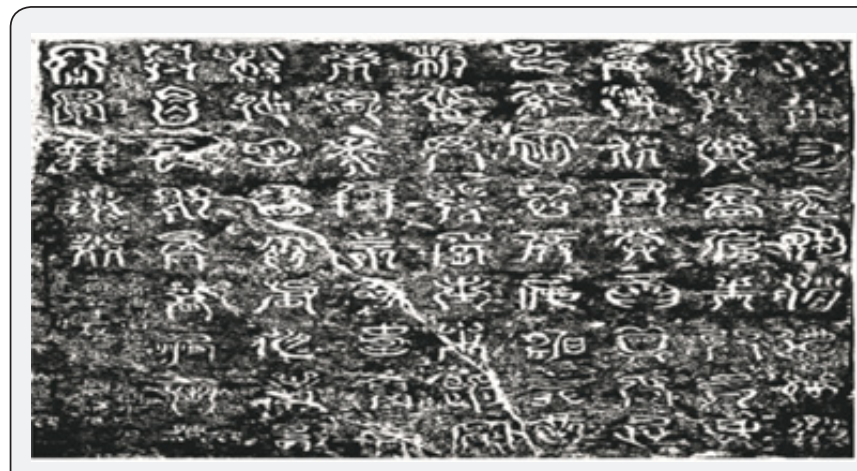

Figure 2: Rubbing of Yu Stele. Reproduced from Changsha Municipal Bureau of Cultural relics.

The illustration shows that Yu Steleis 1.84 meters high and 1.4 meters wide, and inscriptions on it have nine lines together, the first 8 lines with 9 characters and the last line with 5 characters, a total of 77 words. The shape of these characters seems like tadpoles and they are extremely indiscernible. Besides, at the bottom of the last line, there are four regular characters-“engraved by emperor Yu” (右帝禹刻), which telling us that those eccentric characters were coined by Yu the Great. The whole stele was carved by Hezhion Jiading five years of the Southern Song Dynasty (1212).When he found the original one on Mount Hengshan, Hezhi took the inscription down, carried 
the rubbing to Changsha and engraved on Yuelu mountain to pay tribute to Yu the Great. Although the characters bear uncertainty, the time of the engraving can be verified, for another ancient carving adjacent to it offers us evidence (Figure 3).

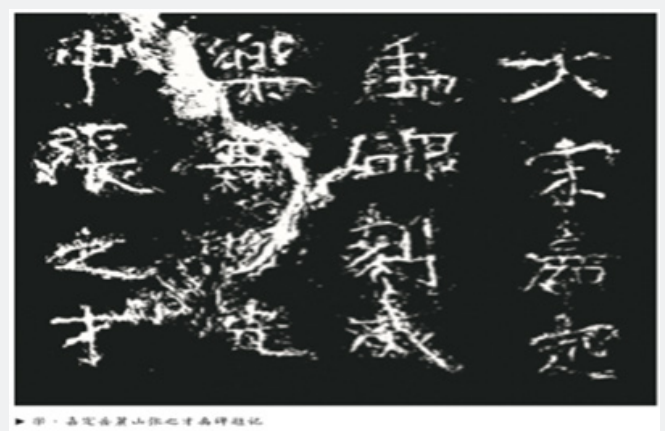

Figure 3: Inscription by Zhang Zhicai in Song Dynasty. Reproduced from Changsha Municipal Bureau of Cultural relics.

This carving done by Zhang zhicai is relatively easy to identify, which says that Yu Stele, engraved in Jiading period of Song Dynasty, brings credit to Hua Xia music and dance (大宋嘉 定，禹碑刻成，邓舞增光，宋內之才).

Later on, many scholars have decoded these tadpoles. Yang Shen (1448-1559), the leading one of three talents in Ming Dynasty, explored and explained them, which is regarded as the most authoritative one. The full text is as follows: “承帝曰咨, 翼輔佐卿。洲渚與登，鳥獸之門。參身洪流，而明發爾興。久 旅忘家，宿岳麓庭。智營形折，心罔弗辰。往求平定，華获泰 衡。宗疏事衰，勞餘伸禋。䍡塞昏徙，南瀆衍亨。衣制食備，

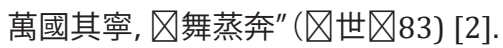

The following is a paraphrase. Xia Yu was instructed by Shundi. Shundi said, "Yu, you are the man who helps me like a pair of powerful wings, so the task of managing the flood will be given to you! You must go to the wild places. No matter how deep the mountains, how winding the roads, how long the rivers, you have to concentrate on it and embark on your journey early tomorrow." Then I started my arduous and glorious journey. I am so focused on it that I even passed by my door three times without entering. I often eat in the winds and sleep in the dews. In spite of my gaunt heart and soul, I am dedicated to the people. Under the extreme condition of the wild miasma, I struggled to move between mountains. I have been to Huayue (in Shanxi province), Mount Tai (in Shandong province) and Nanyue (in Hunan province), etc. Having racked my brain to figure out a way by dredging rather than by blocking breaches in natural levees and having prayed for god's help as well, each river has been dredged and the flow of water converges smoothly. Recently, I have been staying at the foot of Mount Hengshan, where the rivers of the south were well-circulated, and people were wellfed and well-clothed with peace. The flood is gone permanently.

As suggested above, the Yu Stele not only describes a magnificent page of Yu the Great successfully conquering the national flood disaster with the spirit of sstrenuous struggle, inexhaustible intelligence, and selfless quality, but also sheds light on the development of ancient water conservancy in China. Hence, it is safe for us to say that $\mathrm{Yu}$, as one of the few Chinese rulers posthumously honored with the epithet "the Great", is a real culture hero in China.

\section{References}

1. Qinglong Wu, Zhijun Zhao, Li Liu, Darryl E Granger, Hui Wang et al. (2016) Outburst Flood at 1920 BCE Supports Historicity of China's Great Flood and the Xia Dynasty. Science 353: 579-582.

2. $\bigotimes 世 \bigotimes$.大理 $\bigotimes \bigotimes$.金石篇 (第1册) [M].北京: 中国社会科学出版 社, 1994 .

\section{Your next submission with Juniper Publishers will reach you the below assets}

- Quality Editorial service

- Swift Peer Review

- Reprints availability

- E-prints Service

- Manuscript Podcast for convenient understanding

- Global attainment for your research

- Manuscript accessibility in different formats

( Pdf, E-pub, Full Text, Audio)

- Unceasing customer service

Track the below URL for one-step submission

https://juniperpublishers.com/online-submission.php 